\title{
DAMPAK REWARD DAN PUNISHMENT DALAM MEMBENTUK DISIPLIN ANAK USIA 5-6 TAHUN PADA MASA BDR (BELAJAR DARI RUMAH) DI TK PUTRA1 MATARAM
}

\author{
Irwan $^{1^{*}}$, Hully $^{2} \&$ Mariana ulfa ${ }^{3}$ \\ ${ }^{1}$ Universitas Nahdlatul Wathan Mataram, Indonesia \\ ${ }^{2}$ Universitas Islam Negeri Mataram, Indonesia \\ ${ }^{3}$ PAUD Seruni Praya, Indonesia \\ Corresponding author: nawawiirwan1987@gmail.com
}

\author{
Article History \\ Received : March 13 ${ }^{\text {th }}, 2021$ \\ Revised : April $21^{\text {th }}, 2021$ \\ Accepted : May 20 ${ }^{\text {th }}, 2021$ \\ Published : May $27^{\text {th }}, 2021$
}

\begin{abstract}
Abstrak: Salah satu bentuk pengembangan nilai pendidikan karakter pada anak yang dapat membentuk perilaku positif adalah dengan penanaman nilai karakter disiplin. Penelitian ini bertjuan untuk memperoleh data mengenai dampak reward dan punishment dalam membentuk disiplin anak usia 5-6 Tahun pada masa BDR (Belajar Dari Rumah) di TK Putra 1 Mataram. Dalam membentuk disiplin anak usia 5-6 tahun guru di TK Putra 1 Mataram menggunakan metode reward dan punishment. Reward merupakan hadiah, penghargaan yang dijadikan sebagai alat pendidikan dan diberikan ketika anak melakukan hal positif dan mengerjakan sesuatu dengan baik. Sedangkan, punishment yaitu hukuman yang diberikan kepada anak yang melakukan pelanggaran dengan tujuan agar anak merasa jera dan mau memperbaiki kesalahan yang diperbuatnya. Jenis penelitan ini menggunakan pendekatan kualitatif deskriftif dengan fokus penelitian dampak reward dan punishment dalam membentuk disiplin pada anak usia 5-6 tahun pada masa BDR di TK Putra 1 Mataram. Teknik pengumpulan data menggunakan observasi, wawancaa, dan dokumentasi. Adapun yang menjadi sumber data primer adalah Kepala Sekolah TK Putra 1 Mataram dan guru-guru. Sedangkan. sumber data sekundernya yaitu perwakilan orang tua, dokumen, arsip, dan data lainnya. Untuk uji keabsahan data menggunakan triangulasi data. Hasil dari penelitian ini adalah reward dan punishment berdampak positif dalam membentuk disiplin pada anak ketika anak diberikan reward anak menjadi senang dan berusaha menunjukkan sikap positif dan disiplin dan ketika anak diberikan punishment ketika melakukan pelanggaran anak merasa jera dan mau memperbaiki kesalahannya. Adapun bentuk reward dan punishment yang diberikan yaitu kalimat pujian, penghargaan, hadiah, motivasi, sedangkan punishment berupa peringatan dan teguran.
\end{abstract}

Kata kunci: Reward, Punishment, Disiplin.

\section{PENDAHULUAN}

Dalam Pasal 28 Ayat 1 UU Nomor 20 Tahun 2003 tentang Sistem Pendidikan Nasional disebutka bahwa "Anak Usia Dini adalah anak yang berada pada usia 0-6 tahun. (UndangUndang RI No. 20 2003). Kisaran usia ini juga disebut dengan istilah Golden Age yaitu usia emas, karena merupakan usia yang sangat penting dalam proses tumbuh kembang anak, hal ini dikarenakan pada usia tersebut proses pertumbuhan dan perkembangan anak sangat pesat pada semua aspek perkembangannya. Anak usia dini berbeda dengan anak-anak di atas usianya, sehingga anak usia dini memerlukan pembinaan secara lebih khusus untuk menunjang keberhasilan pembentukan karakter pada anak. Oleh karena itu pendidikan merupakan hal yang sangat penting dalam membentuk karakter anak. Salah satu bentuk pengembangan nilai pendidikan karakter pada anak yang dapat membentuk perilaku positif adalah dengan penanaman nilai karakter disiplin.

Hurlock, (2007) menyatakan bahwa "disiplin berasal dari kata yang sama dengan "disciple", yakni seorang yang belajar dari atau secara suka rela mengikuti seorang pemimpin. Disiplin itu sendiri bertujuan untuk membentuk prilaku sedemikian rupa hingga sesuai dengan peran-peran yang ditetapkan oleh kelompok budaya tempat individu tersebut diidentifikasikan (Hurlock, 2007). Lebih jauh 
Hurlock mengatakan bahwa disiplin sangatlah perlu untuk perkembangan anak, karena ia memenuhi beberapa kebutuhan anak sebagai berikut:

1. Disiplin memberikan anak rasa aman dengan memberitahukan apa yang boleh dan tidak boleh dilakukan.

2. Dengan membantu anak menghindari rasa perasaan bersalah dan rasa malu akibat prilaku yang salah - perasaan yang pasti mengakibatkan rasa tidak bahagia dan penyesuaian yang buruk - disiplin memungkinkan anak hidup menurut standar yang disetujui kelompok sosial dan dengan demikian memperoleh persetujuan sosial.

3. Dengan disiplin, anak belajar bersikap menurut cara yang akan mendatangkan pujian yang akan ditafsirkan anak sebagai tanda kasih sayang dan penerimaan. Hal ini esensial bagi penyesuaian yang berhasil dan kebahagiaan.

4. Disiplin yang sesuai dengan perkembngan berfungsi sebagai motivasi pendorong ego yang mendorong anak mencapai apa yang diharapkan darinya.

5. Disiplin membantu anak mengembangkan hati nurani - "suara dari dalam" pembimbing dalam pengambilan keputusan dan pengendalian prilaku (Hurlock, 2007 ).

Dengan demikian menurut paparan di atas artinya disiplin dapat memperbesar kebahagiaan dan penyesuaian pribadi serta sosial anak dalam suatu kelompok yang ditempati. Maka perlunya penanaman disiplin pada anak sangatlah penting bagi kehidupan anak kedepannya. Menurut Widyaning Hapsari dan Itsna Iftayani, (2016) mengemukakan bahwa kedisiplinan sebagai alat pendidikan diterapkan dalam rangka pembentukan, pembinaan dan pengembangan sikap serta tingkah laku yang baik. Sikap dan tingkah laku yang baik tersebut dapat berupa kerajinan, berbudi pekerti luhur, patuh, hormat, tenggang rasa dan berdisiplin. Kedisiplinan dapat mengarahkan siswa untuk menyesuaikan diri dengan cara menaati tata tertib sekolah.

Sebagaimana Hurlock,

(2007) mengatakan bahwa "orang tua dan guru merupakan pemimpin dan anak merupakan murid yang belajar dari mereka. Untuk mencegah anak dalam mengulangi prilaku tidak disiplin, metode reward dan punishment dapat digunakan sebagai stimulus bagi anak agar anak dapat belajar untuk disiplin. Kedua metode ini bersumber dari teori behaviorisme yang dalam proses belajar menggunakan stimulus-respon yaitu rangsangan dan tindakan dari lingkungan. Sehinggametode reward dan punishment merupakan stimulus atau sesuatu yang dapat memberikan ransangan kepada individu. (Zamzami, 2015).

Dalam pendidikan Islam reward (hadiah) disebut dengan istilah "tsawab" dan punishment (hukuman) diistilahkan "iqob". Reward diberikan bagi orang beriman dan beramal sholeh dengan mendapatkan ganjaran pahala dan jaminan surga. Sedangkan punishment atau Iqob ditujukan bagi orang yang berbuat maksiat dan tidak mematuhi perintah dan tidak menjauhi larangan Allah SWT sehingga ganjaran yang didapatkan adalah akan mendapat dosa.

Berkaitan dengan hal tersebut, TK Putra 1 Mataram sudah menerapkan metode reward dan punishment dalam mendisiplinkan anak. Hal tersebut diterapkan dengan cara memberikan bintang dan pujian kepada anak yang berprestasi dan patuh pada peraturan sekolah serta memberi teguran dan peringatan bagi anak yang melanggar tata tertib. Namun mengingat situasi pandemi covid-19 yang sedang berlangsung saat ini mengharuskan sekolah untuk melakukan proses belajar mengajar dari rumah secara online untuk menanggulagi penyebaran covid-19. Akan tetapi hal tersebut tidak menyurutkan usaha guru dalam menerapkan reward dan punishment untuk membentuk disiliplin pada anak usia 5-6 tahun di TK Putra 1 Mataram. Dalam hal ini guru memberikan reward dan punishment kepada anak secara online. Hal tersebut diterapkan dengan cara memberikan tugas kepada anak untuk dikerjakan di rumah kemudian wali murid mengirimkan tugas anak kepada guru. Kemudian murid yang mengerjakan tugas dengan baik diberikan reward berupa bintang pada lembar penilaian kegiatan anak, sedangkan anak yang mengerjakan tugas dengan kurang baik diberi motivasi agar lebih giat lagi belajar.

\section{METODE}

Metode penelitian pada dasarnya merupakan cara ilmiah untuk mendapatkan data dengan tujuan dan kegunaan tertentu. Data yang diperoleh melalui penelitian itu adalah data empiris (teramati) yang mempunyai kriteria tertentu yaitu valid (Sugiono, 2006). Dalam penelitian ini, penulis menggunakan pendekatan kualitatif deskriptif, karena data-data yang akan 
dikumpulkan adalah data-data yang bersifat deskriptif. Berdasarkan pada fenomena kasus yang akan diteliti yaitu dampak reward dan punishment dalam membentuk disiplin anak. Dalam penelitian ini, peneliti secara langsung akan mengumpulkan data melalui observasi, dokumentasi, wawancara dengan informan di lapangan. Agar data yang diperoleh benar keabsahannya, peneliti dalam penelitian ini perlu menggunakan metode penelitian yang tersusun secara sistematis sehingga penelitian ini layak untuk diuji keabsahannya.

\section{HASIL DAN PEMBAHASAN}

\section{Dampak Reward dan Punishment dalam Membentuk Disiplin Anak Usia 5-6 Tahun di TK Pura 1 Mataram Tahun Pelajaran 2019- 2020.}

Pendidikan di Indonesia erat kaitannya dengan reward dan punishment dalam kaitannya dengan pembelajaran dan kedisiplinan guru menerapkan metode untuk memberikan motivasi kepada anak agar lebih disiplin terhadap segala peraturan yang diterapkan di sekolah. Salah satu kebutuhan yang dimiliki siswa adalah kebutuhan penghargaan dalam pembelajaran yaitu dengan pemberian reward dan punishment. Menerapkan metode reward dan punishment dalam proses belajar mengajar, sebagai salah satu lembaga pendidikan yang sangat menjunjung pendidikan karakter salah satunya yaitu kedisiplinan. Sehingga sekolah berupaya semaksimal mungkin menghasilkan siswa yang berprestasi dan berkarakter disiplin ketika sudah memasuki sekolah ke jenjang yang lebih tinggi".

Selain penggunan metode reward dan punishment tersebut, juga menerapkan strategi dalam memberikan reward dan punishment "strategi yang digunakan dalam memberikan reaward dan punishment itu sendiri yaitu dengan memberi penguatan sebelum anak melakukan kegiatan. Reward diberikan oleh guru kepada anak dengan memberi hadiah atas hal positif yang dilakukan oleh anak. Pemberian reward dimaksudkan untuk membentuk anak lebih giat lagi usahanya untuk berbuat lebih baik lagi. Punishment diberkan guru kepada anak karena anak melakukan pelanggaran atau kesalahan. Punishment akan membuat anak menyesali perbuatannya itu. Sehingga dengan adanya reward dan punishment tersebut dapat membuat anak antusias dalam melaksanakan semua kegiatan.
Pada prinsipnya guru telah menggunakan metode reward dan punishment guna membentuk disiplin pada anak usia 5-6 tahun di TK Putra 1 Mataram. Anak yang taat pada tata tertib dan mengerjakan tugasnya dengan baik dan benar diberkan reward oleh guru agar anak termotivasi untuk lebih giat lagi usahanya untuk bekerja dan berbuat lebih baik lagi. Sedangkan guru memberikan punishment berupa teguran kepada anak yang melakukan pelanggaran atau kesalahan.

Jadi dapat disimpulkan bahwa penggunaan metode reward dan punishment untuk membentuk disiplin anak usia 5-6 tahun tersebut telah efektif dilaksanakan pada proses belajar mengajar yaitu dengan cara guru memberikan penguatan kepada anak sebelum proses kegiatan dimulai agar anak termotivasi dalam mengikuti proses belajar mengajar sehingga dapat memberi dampak positif bagi anak maupun guru. Hal tersebut sesuai menurut Widijo yaitu: tujuan dari pemberian reward dan punishment harus jelas agar memberikan dampak yang positive bagi anak dan guru.

\section{Pelaksanaan Reward dan Punishment di TK Putra 1 Mataram}

Setiap anak memiliki karakteristik yang berbeda-beda sehingga guru mempunyai cara tersendiri untuk mengatasi perbedaan tersebut. Dalam memberikan reward dan punishment kepada anak guru harus memperhatikan pelaksanaanya dengan baik agar dapat berdampak positif bagi anak serta guru di sekolah TK Putra 1 Mataram. Memang Reward dan punishment kerap diberikan oleh guru setelah anak selesai melakukan suatu kegiatan sebagai bentuk apresiasi kepada siswa.

Reward diberikan setelah anak melakukan hal positif dengan tujuan agar anak termotivasi untuk mengulang perbuatan potisitiv tersebut seterusnya sedangkan punishment diberikan jika anak melakukan pelanggaran atau kesalahan agar anak merasa jera dan tidak mengulanginya lagi" Penerapan metode reward dan punishment di TK Putra 1 Mataram berjalan dengan baik. Dimana sebelum guru memberikan reward dan punishment kepada anak, guru terlebih dahulu memberikan penguatan kepada anak setiap akan melakukan kegiatan belajar dengan tujuan agar anak termotivasi untuk melakukan hal-hal yang positive dan jera untuk melakukan pelangaran terhadap tata tertib yang sudah disetujui bersama dengananak dan guru. 


\begin{tabular}{|c|c|}
\hline \multicolumn{2}{|c|}{\begin{tabular}{llll}
\multicolumn{2}{c}{ Pelaksanaan } & metode reward dan \\
punishment di & TK & Putral Mataram adalah \\
sebagai berikut
\end{tabular}} \\
\hline a. & $\begin{array}{l}\text { Guru memberi penguatan kepada anak } \\
\text { sebelum memulai proses kegiatan }\end{array}$ \\
\hline b. & $\begin{array}{l}\text { Guru berusaha menghargai anak dan } \\
\text { memberikan tepuk tangan agar anak } \\
\text { merasa percaya diri dan merasa senang }\end{array}$ \\
\hline & $\begin{array}{l}\text { Guru memberi bintang kepada anak } \\
\text { ketika selesai mengerjakan tugas }\end{array}$ \\
\hline d. & $\begin{array}{l}\text { Guru memberikan tanda penghargaan } \\
\text { kepada anak yang berprestasi }\end{array}$ \\
\hline & $\begin{array}{l}\text { Guru memberikan peringatan bagi anak } \\
\text { yang melanggar tata tertib sekolah }\end{array}$ \\
\hline f. & $\begin{array}{l}\text { Guru menerapkan recalling sebelum } \\
\text { pulang sekolah kepada anak agar anak } \\
\text { dapat mengingat dan menjadikan } \\
\text { peringatan yang di berikan oleh guru } \\
\text { sebagai pelajaran untuk tidak } \\
\text { mengulangi kesalahan yang sama di } \\
\text { waktu yang akan datang. }\end{array}$ \\
\hline
\end{tabular}

Dari penjelasan di atas dapat disimpulkan bahwa pelaksanaan metode reward dan punishment di TK Putra 1 Mataram berlangsung dengan cukup baik. Meskipun sekolah diharuskan dari rumah saja karena anjuran dari pemerintah untuk menanggulangi penyebaran covid-19 guru tetap menerapkan reward dan punishment bagi semua murid di TK Putra 1 Mataram agar tetap menjadi motivasi bagi anak untuk lebih giat lagi dalam belajar.

Adapun bentuk-bentuk reward dan punishment yang diterapkan di TK Putra 1 Mataram bermacam-macam berdasarkan hasil wawancara yang dilakukan oleh peneliti bahwa reward dan punishment yang digunakan oleh guru di TK Putra 1 Mataram yaitu:

a. Bentuk Reward

Bentuk reword ini dilakukan dengan

cara: 1) Kalimat pujian. Bentuk ganjaran yang palin mudah dilaksanakn, pujian dapap berupa kata-kata, isyarat, dan juga bisa berupa acungan jempol, dengan tepuk tangan dan sebagainya. 2) Penghormatan. Ganjaran ini dapat berbentuk dua macam yaitu berbentuk penobatan yaitu anak yang mendapatkan penghormatan diumumkan dan ditampilkan dihadapan teman-temnanya. Dan bentuk penghormatan yang berbentuk pemberian kekuasaan untuk melakukan sesuatu. 3) Hadiah berupa benda. Ganjaran yang berbentuk pemberian berupa barang seperti pensil, penggaris, buku tulis dan sebagainya.

\section{b. Bentuk punishment}

Bentuk punishment ini dilakukan dengan cara: 1) Memberikan contoh atau teladan. Dalam memberikan hukuman diberikan contoh, sebab dengan contoh seorang anak akan melihat kesungguhan kita dan akan berusaha mencontoh atau meniru apa yang dilakukan guru. 2) Minta maaf kepada yang bersangkutan. Dalam langkah ini meminta maaf adalah langkah yang paling utama yang harus dilakukan. 3) Berjanji tidak mengulangi. Dalam berjanji tidak akan mengulangi memiliki konsekuensi bahwa dalam diri anak harus ada penanaman berjanji kepada dirinya sendiri, sehingga siswa tidak melakukan kesalahan, mengulangi perbuatan serupa atau kedua, ketiga, bahkan seterusnya.

Hal tersebut dapat dipraktikan di sekolah dengan menggunakan kalimat seperti kalimat pujian, acungan jempol, baik, hebat dan lain-lain. Hal tersebut sesuai dengan teori Soejono yang mengatakan bahwa reward yang diberikan kepada siswa bentuknya bermacam-macam, secara garis besar reward dapat dibedakan menjadi empat bagian yaitu pujian, penghormatan, hadiah, dan tanda penghargaan. Sedangkan bentuk-bentuk punishment yang diterapkan berupa pemberitahuan, peringatan, teguran dan hukuman.Hal ini sesuai dengan teori Yanuar dalam klasifikasi bentuk-bentuk punishment berdasarkan alasan dierapkannya human yaitu bentuk hukuman preventif (Yanuar, A, 2012).

Reward dan punishment tidak hanya di terapkan di sekolah melainkan diterapkan di rumah juga selama menjalani sekolah dari rumah yang dilakukan secara online dalam upaya menanggulangi penularan covid-19 yang sedang berlangsung. Dalam hal ini strategi yang digunakan guru dalam memberikan reward dan punishment selama belajar dari rumah yaitu dengan memberikan kalimat penguatan atau reinforcement kepada anak agar anak dapat termotivasi dalam belajar dan mampu menunjukkan sikap-sikap disiplin. Memberikan reward dan punishment kepada anak berarti memberikan penguatan kepada anak agar mereka tahu tata tertib dalam belajar dan tidak melakukan hal-hal yang tidak baik selama belajar, kalimat penguatan yang kami berikan seperti "baik","hebat", "bagus sekali" dan lainlain".

Sesuai dengan teori Usman dalam Yopi Nisa Febianti, (2018) penguatan (reinforcement) 
merupakan semua bentuk respon,bersifat verbal/nonverbal bagian modifikasi perlaku guru terhadap siswa,dengan pemberian informasi atau umpan balik sebagai tujuan bagi si penerima (siswa) atas perbuatannya, sebagai dorongan ataupun koreksi. Atau penguatan adalah respon terhadap prilaku yang dapat meningkatkan kemungkinan terulangnya kembali prilaku tersebut.

\section{KESIMPULAN}

Metode reward yang diterapkan di TK Putra 1 Mataram menunjukkan dampak yang positif dalam menunjang keberhasilan pembentukan sikap disiplin pada anak usia 5-6 tahun, hal tersebut dilihat dari hasil penelitian yang dilakukan oleh penulis, bahwa ketika anak diberikan reward anak merasa senang dan berusaha untuk meningkatkan prestasinya serta menjadi semangat dalam belajar. Metode reward yang diterapkan berupa gerakan tubuh seperti tepuk tangan, acungan jempol, katakata pujian, memberi motivasi dan semangat, serta hadiah penghargaan.

Sedangkan punishment yang digunakan hanya sebatas teguran dan peringatan. Teguran seperti larangan melakukan kesalahan, tidak boleh, selain itu punishment yang sering digunakan jika anak melakukan kesalahan guru menghukum anak dengan ancaman seperti lebih belakang pulang. Dalam hal ini punishment harus diterapkan dengan baik dan tepat agar tidak berdampak negative bagi anak.

Dari reward dan punishment yang diterapkan oleh guru di TK Putra 1 Mataram selama belajar dari rumah dapat dilihat bahwa disiplin anak dapat meningkat dengan baik, yang tadinya tidak mau mendengarkan arahan dari guru maupun orang tua setelah di berikan punishment anak menunjukkan perubahan prilaku menjadi lebih disiplin setelah menunjukkan perubahan.

\section{REFERENSI}

Elizabeth B. Hurlock (1978). Child Development, (Meitasari \&Tjandrasa). Jakarta: Erlangga.

Muh. Rodhi Zamzami (2015). Penerapan Reward dan Punishment Dalam Teori Belajar Behaviorisme. Ta'limuna, 4 (1).
Kevin Seifert (2012). Pedoman Pembelajaran dan Instruksi Pendidikan. Yogyakarta: IRCiSoD.

Sugiono (2006). Metode Penelitian Kuantitatif Kualitatif dan $R \& D$. Bandung: Alfa Beta.

Undang-Undang RI 2003 No. 20. Sistem Pendidikan Nasional,

Yopi Nisa Febianti (2018). Peningkatan Motivasi Belajar Dengan Pemberian Reward and Punishment Yang Positif. Jurnal Edunomic, 6 (2).

Yanuar, A. (2012). Jenis-jenis Hukuman Edukatif Untuk Anak SD.Yogyakarta: Diva Press.

Widyani Hapsari \& Itsna Iftayani (2017). Model Pendidikan Karakter Pada Anak Usia Dini Melalui Program Islmic Habituation. Jurnal Indegenous, 1 (2). 